\title{
172 REUSE OF AUTOCLAVED INTRAVAGINAL PROGESTERONE DEVICE TO ESTROUS SYNCHRONIZATION IN TOGGENBURG GOATS IN THE BREEDING SEASON
}

\author{
J. M. G. Souza A B, C. A. A. Torres A, M. C. Silva B, A. L. R. S. Maia B C, J. H. Bruschi B, F. Z. Brandão \\ C, J. H. M. Viana B, V. J. F. Freitas D and J. F. Fonseca E
}

A Federal University of Viçosa, Viçosa, MG, Brazil;

B Embrapa Dairy Cattle Research, Juiz de Fora, MG, Brazil;

C Fluminense Federal University, Niterói, RJ, Brazil;

D Ceará State University, Fortaleza, CE, Brazil;

E Embrapa Goats and Sheep Research, Sobral, CE, Brazil

Reproduction, Fertility and Development 23(1) 188-188 http://dx.doi.org/10.1071/RDv23n1Ab172

Published: 7 December 2010

\begin{abstract}
Reusing intravaginal devices represents an important alternative to reduce costs; however, this practice may increase disease transmission. The aim of this study was to evaluate the efficacy of reusing autoclaved intravaginal progesterone devices for oestrous synchronization in Toggenburg goats in the breeding season was studied. This study was done in March and April of 2009, in Piau, MG, Brazil (latitude $21^{\circ} 35^{\prime}$ and longitude $\left.43^{\circ} 15^{\prime}\right)$. Sixty-seven Toggenburg nulliparous $(\mathrm{n}=17 ; 35.3 \pm 5.4 \mathrm{~kg}$ and $3.3 \pm 0.2)$ and pluriparous $(\mathrm{n}=50 ; 52.9 \pm 9.8 \mathrm{~kg}$ and $3.4 \pm 0.3)$ goats were assigned according to weight and body condition score (BCS, 1 to 5 scale) into 3 treatments. Animals received new devices $(\mathrm{n}=25 ; 48.2 \pm 11.5 \mathrm{~kg}$ and $\mathrm{BCS} 3.4 \pm 0.3)$ containing $0.33 \mathrm{~g}$ of progesterone (Eazi-Breed CIDR®, Pfizer Animal Health, São Paulo, Brazil) or autoclaved $\left(121^{\circ} \mathrm{C}, 1 \mathrm{~atm}, 15 \mathrm{~min}\right)$ devices previously used for 6 days $(\mathrm{n}=23 ; 48.3 \pm 13.0 \mathrm{~kg}$ and $3.5 \pm 0.3)$ or 12 days $(\mathrm{n}=22 ; 48.2 \pm 11.0 \mathrm{~kg}$ and $3.4 \pm 0.3)$. All goats received $5 \mathrm{mg}$ dinoprost (Lutalyse ${ }^{\circ}$, Pfizer Animal Health) in the vulvar submucosa on the day of CIDR insertion (Day 0) and 200 IU eCG (Novormon $5000 \AA$, Sintex Indústria Bioquímica, Buenos Aires, Argentina) 1 day before CIDR removal, also in the vulvar submucosa. The CIDR were removed on day 6 , and goats were bred twice daily with fertile bucks at oestrous onset and $24 \mathrm{~h}$ later if they were still in oestrus. Parametric variables were analysed by ANOVA and SNK tests by the SAEG® program. Nonparametric variables were analysed using the chi-square test by the BioEstat ${ }^{\circledR}$ program. The results are described as mean \pm SD. Oestrous response and conception rates did not differ $(\mathrm{P}>0.05)$ among goats treated with the new devices $(75.0 ; 54.2 \%)$ or those previously used for $6(81.8$; $50.0 \%)$ or 12 days $(71.4 ; 47.6 \%)$, respectively. No differences were detected between nulliparous $(82.3$; $52.9 \%)$ and pluriparous $(72.0 ; 50.0 \%)$ goats. The interval from device removal to oestrus and duration of oestrus were not different $(\mathrm{P}>0.05)$ among animals receiving a new device $(39.3 \pm 15.8 ; 30.7 \pm 16.6 \mathrm{~h})$ or previously used devices for $6(32.7 \pm 11.5 ; 31.8 \pm 7.3 \mathrm{~h})$ or 12 day $(40.8 \pm 20.7 ; 32.8 \pm 13.2 \mathrm{~h})$ treatments, respectively, or between nulliparous $(41.6 \pm 14.9 ; 30.9 \pm 13.9 \mathrm{~h})$ and pluriparous $(35.6 \pm 16.8 ; 32.1 \pm 12.8 \mathrm{~h})$ goats. Since no differences were detected in the evaluated variables among goats receiving reused autoclaved devices or new ones, it can be suggested that the autoclaving process did not affect the efficiency of reusing intravaginal progesterone devices for oestrous synchronization in Toggenburg goats in the breeding season. Probably, P4 concentrations in goats receiving reused autoclaved devices reached at least minimum concentrations to promote oestrous response, since a non-treated group would not show oestrus in this level of synchronization as in goats in this study. This technique can be a simple and valuable tool to reduce sanitary risks of disease transmission without altering fertility in goats.
\end{abstract}

CNPq, Pfizer Animal Health, Embrapa Goats, and Sheep Research, CAPES. 